\title{
Pengaruh Konsentrasi dan Interval Pemberian Urin Sapi Fermentasi Terhadap Pertumbuhan Bibit Tebu (Saccharum officinarum L.) Metode Single Bud Planting (SBP).
}

\author{
Author(s): Zainullah Fathul Bari*(1); M. Bintoro ${ }^{(1)}$; N. Bambang Eko Sulistyono ${ }^{(1)}$ \\ (1) Program Studi Teknik Produksi Benih, Jurusan Produksi Pertanian, Politeknik Negeri Jember \\ * Corresponding author: bari.tpb@gmail.com
}

\begin{abstract}
ABSTRAK
Salah satu teknik untuk mengoptimalkan pembibitan bibit tebu yaitu menggunakan metode single bud planting, dengan memberikan zat pengatur tumbuh alami urin sapi fermentasi. Zat pengatur tumbuh sangat penting untuk menentukan pertumbuhan dan perkembangan bibit tebu, akan tetapi konsentrasi dan interval harus diperhatikan. Penelitian ini bertujuan untuk mendapatkan konsentrasi dan interval pemberian urin sapi fermentasi yang tepat. Penelitian dilakukan dibulan agustus-november 2016, menggunakan Rancangan Acak Kelompok (RAK) faktorialterdiri 2 faktor dan diulangan sebanyak 3 kali. Faktor pertama adalah konsentrasi (0\%, 5\%, 10\%, dan 15\%) dan faktor kedua adalah (satu minggu, dua minggu, dan tiga minggu). Hasilnya menunjukkan bahwa urin sapi konsentrasi $15 \%$ memberikan pengaruh nyata pada pertambahan tinggi tanaman, jumlah daun, diameter batang bibit tebu pada umur 56 dan 70 hari setelah tanam. Pemberian urin sapi dengan interval satu minggu memberikan pengaruh yang nyata terhadap pertambahan tinggi bibit tebu pada umur 70 HST. interaksi terbaik penggunaan urin sapi yaitu konsentrasi $15 \%+$ interval satu minggu pengaruh nyata pada panjang akar dan volume akar bibit tebu.
\end{abstract}

\section{Kata Kunci \\ Interval; \\ Konsentrasi; \\ Single Bud \\ Planting;}

Fermentasi

Urin Sapi;

\begin{abstract}
Keywords: $\quad$ One of the techniques to optimize the growth of sugar cane seedlings using single bud planting method is by using a natural growth plant substance e.i urine cow fermentation.

Concentration; $\quad$ The growth plant substance are important to determine the growth and development of Interval; the sugar cane seedlings, but concerned in concentration and interval. The aimed Single bud planting;

Fermented cow urine; research to obtain the concentration and interval application of Fermented Cow Urine on the growth of sugarcane seedlings. The research conducted in August to November 2016, by using Randomized Block Design factorial (RBD) with 2 factors and 3 replications. The first factor was the urine concentrations $(0 \%, 5 \%, 10 \%$, and $15 \%)$, and the second factor was the interval applications (one weeks, two weeks, and three weeks). The result showed that cow urine with $15 \%$ concentration had a significant effect on plant height, number of leaves, stem diameter of seedlings sugarcane at 56 DAP and 70 $D A P$. The application of cow urine at once a week had a significant effect on plant height of seedlings sugarcane at 70 DAP. The best combination was showed on the interval application of cow urine with $15 \%$ concentration per week that had a significant effect on the root lenght and root volume of sugarcane seedlings.
\end{abstract}




\section{PENDAHULUAN}

Tanaman tebu (Saccharum offcinarum L.) adalah komoditi yang sangat dibutuhkan di Indonesia yang diolah untuk menjadi gula. Sistem yang selama ini diterapkan untuk pengadaan bahan tanam seperti rajungan, lonjoran, maupun bagal masih dipandang kurang efektif dan efisien karena waktu pembibitan yang masih lama, kemurnian maupun kesehatan bibit masih kurang terjamin, serta pertumbuhan yang masih belum serempak. Pemecahan masalah yang perlu dipertimbangkan untuk masalah ini ialah penerepan inovasi pembibitan tebu dari negara Kolombia bernama metode single bud planting atau bud chip. single bud planting merupakan metode pembibitan tebu menggunakan satu mata tunas (Putri et al., 2013).

Proses pembibitan tebu single bud planting umumnya terdiri dari dua tahapan yang pertama persemaian satu didalam media pasir selama dua minggu guna menumbuhkan akar serta daun minimal dua helai, dan persemaian dua merupakan penanaman bud chip dalam polybag dalam kurun waktu 3 bulan. Kelebihan metode single bud planting diantaranya pertumbuhan yang serempak, tidak membutuhkan lahan yang luas, umur bibit lebih genjah, tidak membutuhkan bahan tanam yang besar, serta kualitas dan kepastian hidup yang tinggi.

Permasalahan yang ada difase pertumbuhan (vegetatif) adalah lamanya pertumbuhan akar, batang, maupun daun, upaya untuk mempercepat pertumbuhan biasanya menggunakan Zat Pengatur Tumbuh (ZPT). ZPT merupakan suatu senyawa organik tetapi bukan nutrisi dimana dalam konsentrasi tertentu dapat mendorong, maupun menghambat perkembangan tanaman (Leovici, Kastono, \& Putra, 2014). ZPT yang sering digunakan biasanya seperti Gibberellic acid (GA3) dan Asam Naftalenasetat (NAA) akan tetapi harganya lumayan mahal sehingga perlu mencari bahan lain yang mengandung ZPT tersebut, misalnya urin sapi.

Urin Sapi merupakan limbah hewan ternak yang mengandung Auksin dan senyawa Nitrogen. Auksin tersebut diduga terbentuk dari protein hijauan makanannya karena Auksin tidak dibutuhkan ditubuh ternak sehingga harus dikeluarkan dari tubuh (Sitorus et al., 2015).

Urin sapi perlu dilakukan proses fermentasi untuk mengurangi kadar amoniak serta mengurangi bau yang menyengat serta memperbaiki kandungannya dengan menggunakan bakteri. urin sapi yang difermentasi memiliki kandungan yang lebih baik dari pada urin sapi yang tidak difermentasi dan memiliki bau yang kurang menyengat (Martinsari et al., 2010).

Untuk mengembangankan teknologi dengan biaya rendah di dunia pertanian, urin sapi fermentasi dapat menduduki posisi penting sebagai zat pemacu tumbuh maupun pupuk organik. Berkaitan dengan aplikasi perlu memperhatikan konsentrasi serta interval pemberian karena semakin tinggi konsentrasi pemberian ZPT dapat menghambat pertumbuhan begitu juga dengan interval pemberian semakin cepat dapat menyebabkan pemborosan dan semakin jarang dapat menyebabkan tanaman kekurangan unsur-unsur yang diperlukan dari dalam tanah yang diberikan melalui pemberian urin sapi.

Menurut Suryawati et al., (2009), menyatakan bahwa pemberian air seni sapi berpengaruh positif terhadap pertumbuhan stek, dimana air seni sapi fermentasi lebih baik pengaruhnya dibanding air seni sapi segar dengan dosis per tanaman $2 \mathrm{ml} / 20 \mathrm{ml}$ air dengan waktu pemberian 2 minggu sekali sampai stek berumur 12 minggu setelah tanam.

Tujuan dari Penelitian ini untuk mengetahui konsentrasi dan interval yang tepat terhadap pertumbuhan bibit tebu metode single bud planting. 


\section{METODOLOGI}

Penelitian dilaksanakan pada bulan Agustus- November 2016 dilahan Politeknik Negeri Jember. Bahan dan alatyang digunakan antara lain: bibit tebu varietas Bulu Lawang, urin sapi fermentasi, polybag, tanah, pasir, gelas ukur, kompos, label nama, penggaris, gergaji kayu, cangkul, jangka sorong, timba, dan gembor.

Penelitian menggunakan Rancangan Acak Kelompok (RAK) Faktorial yang terdiri 2 faktor dan 3 ulangan. Faktor pertama konsentrasi $\left(\mathrm{K}_{0}=0 \%, \mathrm{~K}_{1}=5 \%\right.$, $\mathrm{K}_{2}=10 \%$, dan $\mathrm{K}_{3}=15 \%$ ). Faktor kedua interval $\left(\mathrm{I}_{1}=\right.$ satu minggu, $\mathrm{I}_{2}=$ dua minggu, danI $_{3}=$ tiga minggu) .

Prosedur penelitian: Pemilihan bibit (Bululawang), bibit yang diambil merupakan tunas pada batang tengah yang diambil menggunakan gergaji kayu. Persemaian, terdiri dari persemaian satu didalam media pasir selama dua minggu guna menumbuhkan akar serta daun minimal dua helai, dan persemaian dua merupakan penanaman bud chip dalam polybag dalam kurun waktu 3 bulan. Aplikasi perlakuan, dimana pemberian urin sapi fermentasi dilakukan sesuai dengan konsentrasi dan interval yang ditentukan dengan jumlah $100 \mathrm{ml}$ pertanaman. dan pemeliharaan, meliputi penyiraman yang dilakukan setiap saat dimana kondisi media tanam sudah mulai kering, pengendalian hama, penyakit, dan gulma, dilakukan monitoring setiap saat guna melihat tingkat serangan, lakukan pengendalian secara manual dan terpadu dan jika tingkat serangan melebihi ambang ekonomi dilakukan pengendalian menggunakan pestisida.

Parameter pengamatan antara lain pertambahan tinggi tanaman,diukur mulai pangkal batang sampai titik tumbuh. Jumlah daun, dihitung daun yang dalam fase pertumbuhan maupun daunyang sudah tumbuh meski dalam keadaan mati. Diameter batang, diukur pada ketinggian 2 cm dari pangkal batang. Pengamatan dilakukan pada saat tanaman berumur 14 HST, 28 HST, 42 HST, 56 HST, dan 70 HST. terakhir adalah variabel pengamatan panjang akar yang diukur dari daerah bonggol sampai ujung akar, serta volume akar yang dikukan dengan cara merendam akar pada gelas ukur yang berisi air kemudian mengamati peningkatan volume air waktu direndam.

Analisis datadilakukan untuk menguji hipotesis dengan analisis anova yaitu Rancangan Acak Kelompok (RAK) faktorial sebagai berikut :

$$
\gamma \mathrm{ij}=\mu+\alpha_{\mathrm{i}}+\beta_{\mathrm{j}}+(\alpha \beta)_{\mathrm{ij}}+\epsilon_{\mathrm{ij}}
$$

Jika berbeda nyata pada tiap faktor dilakukan uji lanjut BNT 5\% dengan rumus sebagai berikut :

$$
\text { BNT } \alpha=\mathrm{t}(\alpha \cdot \mathrm{v}) \cdot \frac{\sqrt{2(\mathrm{KTG})}}{\mathrm{r}}
$$

Sedangkan untuk interaksi kedua faktor jika berbeda nyata dilakukan uji lanjut DMRT 5\% dengan rumus:

$$
\text { DMRT } \alpha=R(\text { b. v. } \alpha) \cdot \frac{\sqrt{\mathrm{KTG}}}{\mathrm{r}}
$$

\section{HASIL DAN PEMBAHASAN Pertambahan Tinggi Tanaman}

Berdasarkan analisis data yang dilakukan diperoleh hasil bahwa faktor konsentrasi (K) hasil fermentasi urine sapi yang diberikan berpengaruh nyata $(*)$ ketika umur 42 HST - 56 HST, dan umr 56 HST - 70 HST, sedangkan faktor interval (I) berpengaruh tidak nyata (ns) terhadap parameter pertambahan tinggi tanaman umur 14 HST - 28 HST, umur 28 HST 42 HST, dan umur 42 HST - 56 HST, tetapi berpengaruh nyata $\left(^{*}\right)$ ketika umur 56 HST - 70 HST, sedangkan interaksi kedua faktor $\left(\mathrm{K}^{*} \mathrm{I}\right)$ berpengaruh tidak nyata (ns) terhadap semua umur pengamatan pertambahan tinggi tanaman. Fermentasi urin sapi berpengaruh tidak nyata pada umur tersebut diduga konsentrasi dan interval yang diberikan belum dapat memacu pembelahan sel dalam proses 
pertumbuhan tinggi tanaman. Beberapa faktor seperti interval dan konsentrasi perlu diperhatikan. Pemberian ZPT tidak boleh berlebihan karena akan menghambat pertumbuhan serta perkembangan tanaman (Leovici et al., 2014).

Berdasarkan Tabel 1 diketahui bahwa pertambahan tinggi tanaman memberikan hasil berpengaruh nyata $(*)$ pada perlakuan konsentrasi $(\mathrm{K})$ umur 42 HST - 56 HST dan umur 56 HST - 70 HST, dan pada perlakuan interval (I) umur 56 HST - 70 HST. Sehingga dilakukan uji lanjut dengan BNT taraf 5\% (Tabel 1 dan Tabel 2).

Tabel 1. Pengaruh Perlakuan Konsentrasi Urin Sapi (K) Terhadap Pertambahan Tinggi Tanaman Tebu Umur 42 HST - 56 HST dan Umur 56 HST - 70 HST (cm)

\begin{tabular}{cc}
\hline Perlakuan $(\mathrm{K} \%)$ & $\begin{array}{c}\text { Pertambahan } \\
\text { Tinggi }(\mathrm{cm})\end{array}$ \\
\hline
\end{tabular}

Umur 42-56HST

$\begin{array}{ll}\left(\mathrm{K}_{0}\right) 0 \% & 2,60 \mathrm{a} \\ \left(\mathrm{K}_{1}\right) 5 \% & 2,68 \mathrm{a} \\ \left(\mathrm{K}_{2}\right) 10 \% & 2,70 \mathrm{a} \\ \left(\mathrm{K}_{3}\right) 15 \% & 2,89 \mathrm{~b}\end{array}$

Umur 56-70 HST

$\begin{array}{ll}\left(\mathrm{K}_{0}\right) 0 \% & 2,59 \mathrm{a} \\ \left(\mathrm{K}_{1}\right) 5 \% & 2,68 \mathrm{ab} \\ \left(\mathrm{K}_{2}\right) 10 \% & 2,76 \mathrm{~b} \\ \left(\mathrm{~K}_{3}\right) 15 \% & 2,80 \mathrm{~b}\end{array}$

Keterangan:

Angka yang diikuti oleh huruf yang sama menunjukan berbeda tidak nyata pada uji BNT 5\%.

Berdasarkan Tabel 1 perlakuan konsentrasi pemberian urin $(\mathrm{K})$ pada konsetrasi $15 \% \quad\left(\mathrm{~K}_{3}\right) \quad$ menunjukan perlakuan terbaik terhadap parameter pertambahan tinggi tanaman $2,89 \mathrm{~cm}$ pada umur 42-56 HST, dan berbeda nyata dengan perlakuan konsetrasi yang lain $0 \%$ $\left(\mathrm{K}_{0}\right)$, 5\% $\left(\mathrm{K}_{1}\right)$, dan $10 \%\left(\mathrm{~K}_{2}\right)$. Sedangkan pada umur 56-70 HST pertambahan tinggi tanaman terbaik $2,80 \mathrm{~cm}$ yaitu konsentrasi $15 \% \quad\left(\mathrm{~K}_{3}\right)$ dan berbeda nyata dengan perlakuan konsetrasi yang lain $0 \%\left(\mathrm{~K}_{0}\right)$, serta $5 \%\left(\mathrm{~K}_{1}\right)$, akan tetapi tidak berbeda nyata dengan konsentrasi pemberian urin sapi fermentasi $10 \%\left(\mathrm{~K}_{2}\right)$. Hal ini diduga dari peranan urin sapi yang mana mengandung unsur senyawa auksin dan unsur nitrogen, senyawa auksin ini dapat memacu perpanjangan sel tanaman. Pendapat Haerul et al., (2015), menyatakan bahwa urin sapi ternyata juga mengandung zat perangsang tumbuh yang dapat digunakan sebagai pengatur tumbuh diantaranya adalah IAA (Asam Indolasetat), Auksin dapat memacu proses pembelahan sel dan pembesaran sel pada batang, sehingga pertumbuhan batang menjadi lebih aktif dan tanaman semakin tinggi.

Tabel 2. Pengaruh Perlakuan Interval Pemberian Urin (I) Terhadap Pertambahan Tinggi Tanaman Tebu Umur 56 HST - 70 HST (cm)

\begin{tabular}{cc}
\hline Perlakuan $(\mathrm{I})$ & $\begin{array}{c}\text { Pertambahan } \\
\text { Tinggi }(\mathrm{cm})\end{array}$ \\
\hline $\mathrm{I}_{2}(2$ minggu $)$ & $2,65 \mathrm{a}$ \\
$\mathrm{I}_{3}(3$ minggu $)$ & $2,68 \mathrm{a}$ \\
$\mathrm{I}_{1}(1$ minggu $)$ & $2,80 \mathrm{~b}$ \\
\hline
\end{tabular}

\section{Keterangan:}

Angka yang didampingi huruf yang sama menunjukan berbeda tidak nyata pada uji BNT 5\%.

Berdasarkan Tabel 2 perlakuan interval pemberian urin (I) pada interval satu (1) minggu $\left(\mathrm{I}_{1}\right)$ menunjukan perlakuan terbaik terhadap parameter pertambahan tinggi tanaman $2,80 \mathrm{~cm}$ dan berbeda nyata dengan perlakuan interval yang lain dua (2) minggu $\left(\mathrm{I}_{2}\right)$, dan tiga (3) minggu $\left(\mathrm{I}_{3}\right)$. Hal ini disebabkan oleh frekuensi waktu pemberian urin yang semakin dekat mengakibatkan tanaman semakin sering menerima unsur senyawa yang terkandung dalam urin sapi sehingga tanaman mampu tumbuh lebih baik dibanding tanaman yang jarang diberi urin sapi. Sesuai dengan pernyataan Silalahi, (2013), seringnya penyemprotan urin sapi membuat tanaman 
semakin banyak menyerap unsur hara sehingga menjadikan tanaman tumbuh dengan baik.

\section{Jumlah Daun}

Parameter jumlah daun pada umur 14 HST, 28 HST, 42 HST tidak berpengaruh nyata pada perlakuan konsentrasi pemberian urine, tetapi berpengaruh nyata (*) ketika berumur 56 HST dan 70 HST, sedangkan faktor interval (I) berpengaruh tidak nyata (ns) terhadap semua parameter pengamatan jumlah daun berdasarkan umur tanaman, begitu juga dengan interaksi kedua faktor $\left(\mathrm{K}^{*} \mathrm{I}\right)$ berpengaruh tidak nyata (ns) terhadap semua parameter pengamatan jumlah daun berdasarkan umur tanaman. Fermentasi urin sapi tidak berpengaruh pada umur tersebut diduga konsentrasi dan interval yang diberikan belum dapat memacu pembelahan sel dalam proses pertumbuhan tinggi tanaman, dengan mengalaminya pertumbuhan tinggi maka akan diikuti pertumbuhan jumlah daun, beberapa faktor seperti interval dan konsentrasi perlu diperhatikan. Pemberian ZPT tidak boleh berlebihan karena akan menghambat laju pertumbuhan (Leovici et al., 2014).

Hasil sidik ragam terhadap parameter jumlah daun berbeda nyata pada perlakuan konsentrasi (K) pada umur 56 dan 70 HST sehingga dilakukan uji lanjut dengan BNT5\% seperti yang tertera pada Tebel 3 .

Perlakuan konsentrasi pemberian urin $(\mathrm{K})$ pada konsetrasi $15 \% \quad\left(\mathrm{~K}_{3}\right)$ menunjukan perlakuan terbaik terhadap parameter jumlah daun pada umur 56 HST (10,20 helai), tidak berbeda nyata dengan perlakuan konsetrasi 5\% $\left(\mathrm{K}_{1}\right)$, dan $10 \%$ $\left(\mathrm{K}_{2}\right)$, tetapi berbeda nyata dengan konsentrasi $0 \%\left(\mathrm{~K}_{0}\right)$, sedangkan pada umur 70 HST (12,34 helai), tidak berbeda nyata dengan perlakuan konsetrasi $10 \%\left(\mathrm{~K}_{2}\right)$, tetapi berbeda nyata dengan konsentrasi $0 \%\left(\mathrm{~K}_{0}\right)$, dan $5 \%\left(\mathrm{~K}_{1}\right)$, Hal ini diduga dari peranan urin sapi yang mana mengandung unsur senyawa auksin dan nitrogen, senyawa auksin ini dapat memacu perpanjangan sel tanaman sehingga dapat meningkatkan pertumbuhan tinggi tanaman dengan mengalaminya pertumbuhan tinggi maka akan diikuti pertumbuhan jumlah daun.

Tabel 3. Pengaruh Perlakuan Konsentrasi Urin Sapi (K) terhadap Jumlah Daun Tanaman Tebu Umur 56 HST dan Umur 70 HST

\begin{tabular}{cc}
\hline Perlakuan K $(\%)$ & Jumlah Daun (Helai) \\
\hline Umur 56 HST & \\
$\left(\mathrm{K}_{0}\right) 0 \%$ & $9,83 \mathrm{a}$ \\
$\left(\mathrm{K}_{1}\right) 5 \%$ & $10,11 \mathrm{~b}$ \\
$\left(\mathrm{~K}_{2}\right) 10 \%$ & $10,14 \mathrm{~b}$ \\
$\left(\mathrm{~K}_{3}\right) 15 \%$ & $10,20 \mathrm{~b}$ \\
\hline Umur $70 \mathrm{HST}$ & \\
$\left(\mathrm{K}_{0}\right) 0 \%$ & $11,92 \mathrm{a}$ \\
$\left(\mathrm{K}_{1}\right) 5 \%$ & $12,18 \mathrm{ab}$ \\
$\left(\mathrm{K}_{2}\right) 10 \%$ & $12,30 \mathrm{~b}$ \\
$\left(\mathrm{~K}_{3}\right) 15 \%$ & $12,34 \mathrm{~b}$ \\
\hline
\end{tabular}

Keterangan :

Angka yang diikuti oleh huruf yang sama menunjukan berbeda tidak nyata pada uji BNT 5\%.

Nasution et al., (2014) menyatakan bahwa besarnya auksin dan unsur hara yang terkandung didalam urin sapi khususnya Nitrogen, membuat tanaman merespon dengan baik pada fase vegetatif, sehingga tanaman mengalami pertumbuhan yang optimal. Air seni merupakan sumber unsur $\mathrm{N}, \mathrm{P}, \mathrm{K}$ yang penting dan urin sapi merupakan salah satu zat pengatur tumbuh alami yang mengandung hormon dari golongan IAA, Giberilin dan Sitokinin. Ferliati, (2013), menyatakan bahwa unsur nitrogen berguna dalam pembelahan dan pembesaran sel-sel yang terjadi pada meristem apikal sehingga memungkinkan pertambahan tinggi tanaman dan pertumbuhan daun yang dapat terbentuk dengan pesat, dimana batang merupakan tempat tumbuhnya daun. 


\section{Diameter Batang}

Hasil analisa pada parameter diameter batang diperoleh bahwa faktor konsentrasi $(\mathrm{K})$ berpengaruh tidak nyata (ns) pada parameter pengamatan diameter batang pada umur 14 HST, 28 HST, 42 HST, tetapi berpengaruh nyata $(*)$ pada umur 56 HST dan 70 HST (Tabel 4), sedangkan faktor interval (I) berpengaruh tidak nyata (ns) terhadap diameter batang berdasakan semua umur pengamatan, begitu juga dengan interaksi kedua faktor $\left(\mathrm{K}^{*} \mathrm{I}\right)$ berpengaruh tidak nyata (ns) terhadap semua parameter pengamatan diameter batang berdasarkan umur tanaman. Pengocoran urin sapi menggunakan interval waktu yang cepat menyebabkan berlebihannya urin. Sebaliknya, bila interval pemberian terlalu jarang dapat menyebabkan kebutuhan hara tanaman kurang terpenuhi, penyebab berbeda tidak nyata (ns) dikarena juga cara pemberian urin yang kurang tepat, sehingga dapat diasumsikan bahwa berapapun lama aplikasi (interval) pemberian urin tidak akan memberikan pengaruh nyata jika aplikasinya kurang tepat, sehingga penyerapan senyawa yang ada didalam kandungan urin tidak diserap secara sempurna oleh tanaman. Patar et al., (2015), menyatakan bahwa penyerapan unsur hara dalam media tanam yang berlangsung dengan baik mengakibatkan pertumbuhan diameter batang yang baik pula.

Berdasarkan Tabel 4 perlakuan konsentrasi pemberian urin $(\mathrm{K})$ pada konsetrasi $15 \quad \% \quad\left(\mathrm{~K}_{3}\right)$ menunjukan perlakuan terbaik terhadap parameter diameter batang ketika umur 56 HST $(1,00$ $\mathrm{cm})$ dan umur 70 HST $(1,18 \mathrm{~cm})$, berbeda tidak nyata dengan perlakuan konsetrasi 5 $\%\left(\mathrm{~K}_{1}\right)$, dan $10 \%\left(\mathrm{~K}_{2}\right)$, tetapi berbeda nyata dengan konsentrasi $0 \%\left(\mathrm{~K}_{0}\right)$. Hal ini diduga karenakan ketersediaan senyawa auksin dan unsur hara makro lain yang terkandung dalam urin sapi telah mampu merangsang fase pertumbuhan (vegetatif) tanaman tebu, dan penyerapan unsur hara dalam media tanam yang berlangsung dengan baik mengakibatkan pertumbuhan diameter batang yang baik pula. Patar et al., (2015) menyatakan bahwa penyerapan unsur hara dalam media tanam yang berlangsung dengan baik mengakibatkan pertumbuhan diameter batang yang baik pula.

Tabel 4. Pengaruh Perlakuan Konsentrasi Urin Sapi (K) Terhadap Diameter Batang Tanaman Tebu Umur 56 HST dan umur 70 HST

\begin{tabular}{cc}
\hline Perlakuan $(\mathrm{K} \%)$ & Diameter Batang \\
\hline Umur 56 HST & \\
$\left(\mathrm{K}_{0}\right) 0 \%$ & $0,92 \mathrm{a}$ \\
$\left(\mathrm{K}_{1}\right) 5 \%$ & $0,97 \mathrm{ab}$ \\
$\left(\mathrm{K}_{2}\right) 10 \%$ & $0,99 \mathrm{~b}$ \\
$\left(\mathrm{~K}_{3}\right) 15 \%$ & $1,00 \mathrm{~b}$ \\
\hline Umur $70 \mathrm{HST}$ & \\
$\left(\mathrm{K}_{0}\right) 0 \%$ & $1,04 \mathrm{a}$ \\
$\left(\mathrm{K}_{1}\right) 5 \%$ & $1,11 \mathrm{ab}$ \\
$\left(\mathrm{K}_{2}\right) 10 \%$ & $1,12 \mathrm{ab}$ \\
$\left(\mathrm{K}_{3}\right) 15 \%$ & $1,18 \mathrm{~b}$ \\
\hline
\end{tabular}

Keterangan:

Angka yang diikuti oleh huruf yang sama menunjukan berbeda tidak nyata pada uji BNT 5\%.

\section{Panjang Akar}

Hasil sidik ragam terhadap parameter panjang akar menunjukkan adanya interaksi yang berbeda nyata $\left({ }^{*}\right)$ dari kedua faktor yaiitu faktor konsentrasi dan interval $(\mathrm{K} * \mathrm{I})$ sehingga dilakukan uji lanjut dengan DMRT taraf 5\%. Seperti yang terlihat pada Tabel 5 berikut ini.

Berdasarkan Tabel 5 dapat dilihat bahwa kombinasi perlakuan antara konsentrasi urin $15 \%$ dan interval pemberian satu (1) minggu $\left(\mathrm{K}_{3} \mathrm{I}_{1}\right)$ menghasilkan panjang akar yang lebih baik, dibandingkan dengan kombinasi perlakuan yang lain yaitu sebesar 37,80 $\mathrm{cm}$. Hal ini terjadi karena konsentrasi $15 \%$ $\left(\mathrm{K}_{3}\right)$ lebih tinggi dari konsentrasi yang lain $0 \%\left(\mathrm{~K}_{0}\right), 5 \%\left(\mathrm{~K}_{1}\right)$, dan $10 \%\left(\mathrm{~K}_{2}\right)$, faktor interval satu (1) minggu ( $\left.\mathrm{I}_{1}\right)$ lebih sering 
pengaplikasiannya dibanding interval dua (2) minggu $\left(\mathrm{I}_{2}\right)$, dan interval tiga (3) minggu $\left(\mathrm{I}_{3}\right)$, sehingga dengan konsentrasi $15 \%$ dan interval satu (1) minggu $\left(\mathrm{K}_{3} \mathrm{I}_{1}\right)$ perlakuan tersebut lebih memenuhi kebutuhan tanaman akan kandungan senyawa yang terkandung dalam urin sapi seperti unsur Auksin dan unsur hara makro lainnya yang dibutuhkan oleh tanaman untuk merangsang pertumbuhan akar dan bagian lainnya dari pada perlakuan dari kombinasi lain.

Tabel 5. Interaksi Konsentrasi (K) dan Interval (I) Pada Parameter Panjang Akar

\begin{tabular}{|c|c|}
\hline Interaksi K x I & $\begin{array}{l}\text { Panjang Akar } \\
(\mathrm{cm})\end{array}$ \\
\hline $\mathrm{K}_{0} \mathrm{I}_{1}(0 \% \mathrm{x} 1 \mathrm{minggu})$ & $28,87 \mathrm{a}$ \\
\hline $\mathrm{K}_{0} \mathrm{I}_{3}(0 \% \times 3 \mathrm{minggu})$ & $29,23 \mathrm{ab}$ \\
\hline $\mathrm{K}_{0} \mathrm{I}_{2}(0 \% \times 2 \mathrm{minggu})$ & $30,00 \mathrm{ab}$ \\
\hline $\mathrm{K}_{1} \mathrm{I}_{3}(1 \% \times 3$ minggu $)$ & $30,88 \mathrm{abc}$ \\
\hline $\mathrm{K}_{1} \mathrm{I}_{2}(1 \%$ x $2 \mathrm{minggu})$ & $31,12 \mathrm{bcd}$ \\
\hline $\mathrm{K}_{1} \mathrm{I}_{1}(1 \% \times 1 \mathrm{minggu})$ & $32,53 \mathrm{~cd}$ \\
\hline $\mathrm{K}_{2} 1_{3}(2 \%$ x 3 minggu $)$ & $32,55 \mathrm{~cd}$ \\
\hline $\mathrm{K}_{2} \mathrm{I}_{2}(2 \% \times 2 \mathrm{minggu})$ & $32,57 \mathrm{~cd}$ \\
\hline $\mathrm{K}_{3} 1_{3}(3 \%$ x 3 minggu $)$ & $33,20 \mathrm{de}$ \\
\hline $\mathrm{K}_{3} \mathrm{I}_{2}(3 \% \times 2$ minggu $)$ & 34,80 ef \\
\hline $\mathrm{K}_{2} \mathrm{I}_{1}(2 \%$ x $1 \mathrm{minggu})$ & $36,52 \mathrm{fg}$ \\
\hline $\mathrm{K}_{3} \mathrm{I}_{1}(3 \%$ x $1 \mathrm{minggu})$ & $37,80 \mathrm{~g}$ \\
\hline
\end{tabular}

Keterangan :

Angka yang diikuti oleh huruf yang sama menunjukan berbeda tidak nyata pada uji BNT 5\%.

Menurut Yunanda et al., (2015) Auksin yang dihasilkan oleh tanaman tersebut akan dialokasikan ke bagian bawah bahan stek untuk membantu perkembangan akar dan jika kemampuan akar untuk menyerap unsur hara semakin tinggi maka proses fotosintesis akan berjalan baik sehingga fotosintat yang dihasilkan akan dialokasikan keseluruh bagian tanaman termasuk untuk pertumbuhan akar.

\section{Volume Akar}

Hasil sidik ragam terhadap parameter volume akar menunjukkan adanya interaksi berbeda nyata $(*)$ dari kedua faktor $\left(\mathrm{K}^{*} \mathrm{I}\right)$ sehingga dilakukan uji lanjut dengan DMRT taraf 5\%. Berdasarkan Tabel 6 kombinasi $\left(\mathrm{K}_{3} \mathrm{I}_{1}\right)$ antara konsentrasi urin $15 \%\left(\mathrm{~K}_{3}\right)$ dan interval satu (1) minggu $\left(\mathrm{I}_{1}\right)$ menghasilkan nilai volume akar tertinggi dibandingkan dengan kombinasi perlakuan yang lain yaitu sebesar 216, $64 \mathrm{ml}$. Hal ini terjadi karena konsentrasi $15 \%\left(\mathrm{~K}_{3}\right)$ lebih tinggi dari konsentrasi lain $0 \%\left(\mathrm{~K}_{0}\right), 5 \%\left(\mathrm{~K}_{1}\right)$, dan $10 \%\left(\mathrm{~K}_{2}\right)$, faktor interval satu (1) minggu $\left(\mathrm{I}_{1}\right)$ lebih sering dibanding interval dua (2) minggu $\left(\mathrm{I}_{2}\right)$, dan interval tiga (3) minggu ( $\left.\mathrm{I}_{3}\right)$, sehingga dengan konsentrasi $15 \%$ dan interval satu (1) minggu $\left(\mathrm{K}_{3} \mathrm{I}_{1}\right)$ perlakuan tersebut lebih memenuhi kebutuhan tanaman akan kandungan senyawa yang terkandung dalam urin sapi seperti unsur auksin dan unsur hara makro lainnya yang dibutuhkan oleh tanaman untuk merangsang pertumbuhan akar dan bagian lainnya dari pada perlakuan dari kombinasi lain. Perkembanganpanjang akar akan mempengaruhi volume akar karena semakin panjang akar suatu tanaman maka volumenya juga semakin meningkat.

Pendapat Yunanda et al., (2015) menyatakan bahwa auksin yang dihasilkan oleh tanaman tersebut akan dialokasikan ke bagian bawah bahan stek untuk membantu perkembangan akar dan jika kemampuan akar untuk menyerap unsur hara semakin tinggi maka proses fotosintesis akan berjalan baik sehingga fotosintat yang dihasilkan akan dialokasikan keseluruh bagian tanaman termasuk untuk pertumbuhan akar, Panjang akar erat kaitannya dengan jumlah akar yang terbentuk sehingga akan menentukan besarnya volume akar. 
Tabel 6. Interaksi Konsentrasi (K) dan Interval (I) Pada Parameter Volume Akar

\begin{tabular}{|c|c|}
\hline Interaksi (K x I) & $\begin{array}{l}\text { Volume Akar } \\
\text { (ml) }\end{array}$ \\
\hline $\mathrm{K}_{0} \mathrm{I}_{3}(0 \%$ x $3 \mathrm{minggu})$ & $156,69 \mathrm{a}$ \\
\hline $\mathrm{K}_{0} \mathrm{I}_{2}(0 \% \times 2 \mathrm{minggu})$ & $160,35 \mathrm{a}$ \\
\hline $\mathrm{K}_{0} \mathrm{I}_{1}(0 \% \times 1 \mathrm{minggu})$ & $162,67 \mathrm{a}$ \\
\hline $\mathrm{K}_{1} \mathrm{I}_{3}(1 \% \times 3 \mathrm{minggu})$ & $186,00 \mathrm{~b}$ \\
\hline $\mathrm{K}_{1} \mathrm{I}_{2}(1 \% \times 2 \mathrm{minggu})$ & $186,15 \mathrm{~b}$ \\
\hline $\mathrm{K}_{1} \mathrm{I}_{1}(1 \% \mathrm{x} 1 \mathrm{minggu})$ & $187,82 \mathrm{bc}$ \\
\hline $\mathrm{K}_{2} \mathrm{I}_{2}(2 \% \times 2 \mathrm{minggu})$ & $189,49 \mathrm{bc}$ \\
\hline $\mathrm{K}_{3} \mathrm{I}_{3}(3 \% \times 3 \mathrm{minggu})$ & $189,67 \mathrm{bc}$ \\
\hline $\mathrm{K}_{2} \mathrm{I}_{3}(2 \% \times 3 \mathrm{minggu})$ & $189,84 \mathrm{bc}$ \\
\hline $\mathrm{K}_{2} \mathrm{I}_{1}(2 \% \times 1 \mathrm{minggu})$ & $197,14 \mathrm{~cd}$ \\
\hline $\mathrm{K}_{3} \mathrm{I}_{2}(3 \% \times 2 \mathrm{minggu})$ & $206,82 \mathrm{de}$ \\
\hline $\mathrm{K}_{3} \mathrm{I}_{1}(3 \% \times 1 \mathrm{minggu})$ & $216,64 \mathrm{e}$ \\
\hline
\end{tabular}

Keterangan :

Angka yang diikuti oleh huruf yang sama menunjukan berbeda tidak nyata pada uji DMRT $5 \%$.

\section{KESIMPULAN}

Berdasarkan hasil penelitian ini diperoleh kesimpulan sebagai berikut :

1. Perlakuan konsentrasi urin sapi $(\mathrm{K})$ berpengaruh nyata $(*)$ terhadap parameter pertambahan tinggi tanaman umur 42 HST - 56 HST dan umur 56 HST - 70 HST, jumlah daun umur 56 HST dan 70 HST, diameter batang umur 56 HST dan 70 HST, dan berpengaruh sangat nyata $(* *)$ terhadap parameter panjang akar dan volume akar, konsentrasi $15 \% \quad\left(\mathrm{~K}_{3}\right)$ menunjukkan perlakuan konsentrasi terbaik terhadap parameter tersebut.

2. Perlakuan interval pemberian urin sapi (I) berpengaruh nyata $\left(^{*}\right)$ terhadap parameter pertambahan tinggi tanaman umur 56 HST - 70 HST, dan berpengaruh sangat nyata $(* *)$ terhadap parameter panjang akar dan volume akar, interval satu (1) minggu ( $\left.\mathrm{I}_{1}\right)$ menunjukkan perlakuan interval terbaik terhadap parameter tersebut.

3. Terdapat interaksi antara konsentrasi dan interval pemberian urin sapi fermentasi terhadap parameter panjang akar dan volume akar, konsentrasi 15\% $\left(\mathrm{K}_{3}\right)$ dan interval pemberian satu minggu $\left(\mathrm{I}_{1}\right)\left(\mathrm{K}_{3} \mathrm{I}_{1}\right)$ menghasilkan nilai tertinggi terhadap parameter tersebut.

\section{DAFTAR PUSTAKA}

Ferliati, D. (2013). Pertumbuhan dan 尌 Produksi Umbi Tanaman Kentang (Solanum Tuberosum L.) Varietas Granola Dari Bibit G0 yang Diberi Zat Pengatur Tumbuh. Formica, 1(1).

Haerul, H., Muammar, M., \& Isnaini, J. L. (2015). Pertumbuhan dan Produksi Tanaman Tomat (Solanum Lycopersicum L) terhadap Poc (Pupuk Organik Cair). Jurnal Agrotan, 1(2), 69-80.

Leovici, H., Kastono, D., \& Putra, E. T. S. (2014). Pengaruh Macam dan Konsenterasi Bahan Organik Sumber Zat Pengatur Tumbuh Alami Terhadap Pertumbuhan Awal Tebu (Saccharum officinarum L.). Vegetalika, 3(1), 22-34.

Martinsari, T., Wijayanti, Y. W., \&

El Purwanti, E. (2010). Optimalisasi Fermentasi Urine Sapi dengan Aditif Tetes Tebu (Molasses) untuk Menghasilkan Pupuk Organik Cair yang Berkualitas Tinggi (Program Kreatif Mahasiswa). Universitas Negeri Malang.

Nasution, L. W., Barus, A., Mawarni, L., \& 尌 Tarigan, R. (2014). Perkecambahan dan Pertumbuhan Bibit Biwa (Eriobotrya japonica Lindl.) Akibat Perendaman Pada Urin Hewan dan Pemotongan Benih. Agroekoteknologi, 2(4), 1367-1375.

Patar, H., Barus, A., \& Irsal. (2015). 彭 Pengaruh Konsentrasi Zat Pengatur 
Tumbuh Dan Sumber Bud Chips terhadap Pertumbuhan Bibit Tebu (Saccharum Officinarum) diPottray. Agroekoteknologi, 3(3), 992-1004.

Putri, A. D., Sudiarso, S., \& Islami, T. (2013). Pengaruh komposisi media tanam pada teknik bud chip tiga varietas tebu (Saccharum officinarum L.). Jurnal Produksi Tanaman, 1(1), 16-23.

Silalahi, S. G. (2013). Pengaruh 钢 Konsentrasi Urine Sapi Dengan Dua Interval Penyemprotan terhadap Pertumbuhan Tanaman Sawi Hijau (Brassica Junceal.) (Skripsi). Universitas Islam Negeri Sultan Syarif Kasim Riau.

Sitorus, M. R., Irmansyah, T., \& Sitepu, F. E. (2015). Respons Pertumbuhan Bibit Setek Tanaman Buah Naga Merah (Hylocereus Costaricencis (Web) Britton \& Ross) terhadap Pemberian Auksin Alami dengan Berbagai Tingkat Konsentrasi. Agroekoteknologi, 3(4), 1557-1565.

Suryawati, S., Sucipto, \& Syamsiyah, N. 尌 (2009). Efektifitas Aplikasi Air Seni Sapi terhadap Pertumbuhan Stek Sulur Tanaman Cabe Jamu (Piper Retrofractum Vahl.). Agrovigor, 2(2), 97-102.

Yunanda, J., Murniati, \& Yoseva, S. 豇 (2015). Pertumbuhan Stek Batang Tanaman Buah Naga (Hylocereus Costaricensis)ss Dengan Pemberian Beberapa Konsentrasi Urin Sapi. JOM Faperta, 2(1), 1-8. 